\title{
Dragana Špica
}

\section{Izgovor japanskog mornog nazala /N/ kod hrvatskih učenika}

Izvorni znanstveni rad

Original scientific paper

UDK 811.521'243:811.521.342.57

https://doi.org/10.32728/tab.18.2021.8

\section{SAŽETAK}

Japanski morni nazal /N/ podspecificirani je nazalni segment s posebnim statusom u japanskome glasovnom sustavu. Za učenike japanskoga čiji je materinski jezik hrvatski /N/ može predstavljati izazov jer podrazumijeva fonološke procese koji ne postoje u hrvatskome. Taj segment stječe različita obilježja ovisno o kontekstu. Cilj je ovoga rada empirijski utvrditi kako učenici japanskoga, čiji je materinski jezik hrvatski, artikuliraju morni nazal /N/, koji od promatranih 8 njegovih ostvaraja predstavljaju poteškoću te koje vrste odstupanja postoje. Predstavljeni su rezultati provedenoga ispitivanja, u kojemu je sudjelovalo 24 studenata Sveučilišta Jurja Dobrile u Puli, od kojih 15 na početnoj i 9 na srednjoj razini. Podatci pokazuju različitu učestalost odstupanja pri izgovoru /N/ ispred stanke, ispred poluvokala /w/ i /j/ i drugdje, dok se najznatnija učestalost odstupanja uočava pri izgovoru /N/ u međuvokalskom položaju. Odstupanje u međuvokalskom položaju tiče se distinktivnoga obilježja te se smatra da ima fonološki značaj, a učestalost je visoka na obje razine učenja. Odstupanja / $\mathrm{N}$ / ispred poluvokala i frikativa te u ostalim kontekstima nisu pokazala fonološki značaj, već samo fonetski.

Ključne riječi: japanski, fonologija, mora, morni nazal, uvularni nazal, nastava stranih jezika, učenje stranih jezika 


\section{UVOD}

Predmet je ovoga rada japanski morni nazal /N/ koji se smatra posebnom morom, odnosno posebnim segmentom (fonemom). To je podspecificirani segment (Ito 1987, citirano u Youngberg 2021: 2) čija je bitna značajka nazalnost i trajanje od jedne more, dok mu mjesto tvorbe određuje konsonant koji slijedi. U određenim kontekstima ostvaruje se kao nazalni vokal. Osim toga, izaziva nazalizaciju prethodnoga vokala. Neki od ostvaraja toga fonema ne postoje u hrvatskome i rijetko se javljaju u svjetskim jezicima te njihov izgovor predstavlja problem učenicima ${ }^{1}$ japanskoga čiji je materinski jezik hrvatski, bez obzira na razinu.

Budući da pravilan izgovor predstavlja bitan dio komunikacijske kompetencije, provedeno je ispitivanje s ciljem utvrđivanja u kojoj mjeri i na koji način dolazi do odstupanja u izgovoru ostvaraja ovoga fonema. Da bi se odstupanja u izgovoru stranoga jezika savladala, najprije ih je potrebno registrirati i opisati. Odstupanja se mogu podijeliti na (a) fonološka, pri kojima se odstupa od razlikovnih obilježja te može biti narušena komunikacija, i (b) fonetska, koja komunikaciju ne narušavaju, ali govornika identificiraju kao neizvornog ${ }^{2}$. U ovome radu pokušat ćemo utvrditi koja od utvrđenih odstupanja u izgovoru mornoga nazala imaju fonetski, a koja fonološki značaj.

U sljedećem dijelu rada opisujemo značajke mornoga nazala /N/, sagledavajući kako stječe različita obilježja u ovisnosti o kontekstu, a zatim ćemo u trećem dijelu dati napomene o vrstama izgovornih odstupanja. Četvrti dio bavi se samim empirijskim istraživanjem, a peti podatcima i njihovom analizom.

\section{MORNI NAZAL /N/ U JAPANSKOM}

Morni nazal /N/ (hatsuon) predstavlja jednu od tri posebne more, odnosno posebna segmenta japanskoga glasovnog sustava. Mora (haku) je osnovna jedinica prozodije i ritma japanskoga jezika, ali i osnovna jedinica glasovnoga sustava prema predodžbi izvornih govornika. Japansko fonetsko pismo kana bilježi upravo more. U tradicionalnoj se japanskoj znanosti o jeziku more dijele na nezavisne i zavisne (posebne). Nezavisne se sastoje (a) samo od

1 U ovome radu naziv učenik koristit ćemo u smislu osobe koja uči te njime obuhvaćamo i studente.

20 tipovima odstupanja pogledati Desnica-Žerjavić $(1993,1998)$ i Šporčić $(2020: 178)$. 
vokala ili (b) od konsonanta i vokala. Zavisne ili posebne more su vokalska dužina /R/ i prvi segment udvojenih konsonanata, glotalni okluziv bez otpusta $/ \mathrm{Q} /{ }^{3}$ te morni nazal $/ \mathrm{N} /{ }^{4}$.

Iz aspekta raspodjele glasova u slogu, /N/ funkcionira isključivo kao koda, odnosno nalazi se na rubu (kraju) sloga. Slog u japanskome predstavlja prozodijsku jedinicu više razine od more te se jedan slog sastoji od jedne ili više mora. Slogovi na čijem se rubu javlja /N/ obično imaju strukturu $\mathrm{V}+/ \mathrm{N} / \mathrm{ili} \mathrm{CV}+/ \mathrm{N} /$. Ovdje je V jedan od 5 vokala: [a], [i], [u], [e], [o]. Primjeri su $\mathrm{V}+\mathrm{N} /$ an 'pire od azuki graha', en 'krug; jen', on 'moralna obveza, dug.' C je jedan od 14 konsonantskih fonema: /p/,/t/,/k/,/s/, /h/,/b/,/d/,/g/,/z/, /m/, /n/, /r/, /w/, /j/ (Shibatani 1990: 159; Kubozono 2015: 8). Primjeri slogova strukture CV+/N/ su: kan 'konzerva', hon 'knjiga', shin' grafitna mina za olovku' te jun 'redoslijed'. Da bismo razlučili razinu more i sloga, pogledat ćemo primjer binkan 'osjetljiv': ta riječ ima 4 more /bi.n.ka.n/, a dva sloga /bin-kan/. Nazivom konsonant ovdje obuhvaćamo i sonante, a /w/ i /j/ nazivat ćemo i poluvokalima. Navedenih 14 konsonantskih fonema obuhvaća

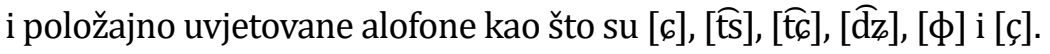

/N/ je (pored /Q/) jedina japanska mora koja ne sadrži neki od pet vokala, [a], [i], [u], [e] ili [o]. /N/ traje jednu moru, isto kao i, primjerice, [ka], [te] ili [i]. Važna značajka mornoga nazala /N/ je i to da se obilježje nazalnosti suprasegmentalno prostire ne samo na konsonant koji slijedi već i na prethodni vokal, što se po konvenciji bilježi pomoću tilde iznad vokala, kao u hon [hõN] 'knjiga'. Što se tiče transkripcije uvularnoga nazala, koristit ćemo oznaku [N], veliki N umanjenoga fonta, koja se koristi u međunarodnoj fonetskoj transkripciji (IPA).

U japanskome također postoji alveolarni nazal [n] kao dio mora [na] / [ni] / [nu] / [ne] / [no]. Ponekad se naziva submorni nazal (Akamatsu 1997: 153) i može se javiti na početku riječi. U položaju ispred [i] alveolar [n] se u mori ni realizira palatalno, kao [ni]. Alveolarni se nazal, koji se nalazi na početnoj poziciji more, razlikuje od /N/ po tome što ne sudjeluje u jednačenjima po mjestu tvorbe, niti izaziva nazalizaciju prethodnoga vokala kao što je slučaj kod /N/. Alveolarni nazal /n/ nije predmet ovoga rada.

3 U literaturi se taj glas opisuje i kao grkljanski prekidnik (Jelaska 2004: 53). U literaturi koja se odnosi na japanski spominje se i kao konsonantska dužina.

4 Labrune (2012: 133) navodi da je Hamada (1949) jedan od prvih japanskih jezikoslovaca koji ističe ove tri more kao segmente različite od drugih mora. 
U nastavku ćemo predstaviti ostvaraje mornoga nazala u različitim fonološkim kontekstima.

\section{uvularni nazal [N]}

U podrazumijevanome kontekstu, što znači u izolaciji ili ispred stanke, za /N/ se smatra da se artikulira uvularno (Shibatani 1990: 170), tako što stražnji dio jezika dodiruje resicu ili uvulu ${ }^{5}$. Primjeri su: Nihon [nihõN] 'Japan', yon [yõN] 'četiri'.

\section{vokal neodređenoga mjesta artikulacije [ũ ]}

Prema Akamatsuu (1997: 57), ispred nekog od pet vokala [a] / [i] / [u] / [e] / [o], poluvokala [u] / [j] i frikativa te njihovih inačica [\$] / [s] / [z] / [ç] / [6] / [बुz] / [h] morni se nazal /N/ ostvaruje kao nazalni vokal ${ }^{7}$ neodređenoga mjesta artikulacije (Akamatsu 1997: 55-57) i u ovome radu prihvaćamo takav pristup ${ }^{8}$. Za bilježenje ove skupine glasova u sva tri konteksta koristit ćemo fonetsku oznaku [ũ], koju predlaže Vance (2008: 100), citirao Maekawa (2021). Primjeri za /N/ u tri različita konteksta su:

(a) ispred vokala: san'en [sãũeN] 'tri jena', kan'i [kãũi] 'priručno'. /N/ ispred vokala naziva se i međuvokalskim jer zbog strukture japanske more (V ili CV) i činjenice da se morni nazal može javiti samo na kraju sloga, mornome nazalu obvezno mora prethoditi vokal. Isti se tip vokala neodređenoga mjesta artikulacije također može naći u prozodijskoj riječi, odnosno ako nakon riječi na čijem je kraju /N/ stoji, primjerice, padežna čestica $o$ akuzativnoga značenja, kao u sen $o$ 'tisuću' [seũ.o]. Prirodu ovoga glasa objašnjava Vance (2018: 139), koji opisuje [ũ] u međuvokalskom položaju kao segment nalik na vokal koji funkcionira kao konsonant;

(b) /N/ ispred poluvokala: denwa [dẽũụa] 'telefon', kin'yoobi [kĩũjoobi] i

5 Dodajmo, ipak, i da novija istraživanja (Nogita-Yamane 2015) navode da se /N/ ispred stanke kod velikoga broja govornika također artikulira i bilabijalno, kao [m].

6 Za detaljan pregled literature u kojoj se /N/ opisuje kao uvular, pogledati Maekawa (2021: 2).

7 Saitō (2003) smatra da je /N/ ispred frikativa i njihovih alofona nazalni frikativ (citirano u Labrune 2012: 133).

8 I ovdje se mišljenja razilaze. Toki (2021) smatra da se ovdje /N/ realizira kao uvularni nazal [N]. 
(c) /N/ ispred frikativa i njihovih alofona, kao u: sensei [sẽũsee] 'učitelj', densha [dẽụ̃a] 'vlak', kanji [kãũûdzi] 'ideogram'.

To nije jedini način sagledavanja i bilježenja toga segmenta te nalazimo sen o 'tisuću' [seẽ.o] (Saitō 2020: 94), kensa [keẽsa] 'ispitivanje' i denwa [deẽwa] (Saitō 2003: 16). Saitō čak navodi (2003: 16) da ispred visokoga vokala [i] često dolazi i do gubljenja i same nazalnosti ovog segmenta, sugerirajući da se gen'in 'razlog' artikulira kao [geein].

\section{bilabijalni nazal [m]}

Ispred oralnih i nazalnih labijalnih praskavaca [p], [b], [m], /N/ se ostvaruje kao [m], kao u riječima sanpo [sãmpo] 'šetnja', sanmai [sãmmai] 'tri (tanka predmeta)'. U riječi sanmai /N/ predstavlja prvi segment geminiranoga konsonanta $/ \mathrm{m} /$.

\section{alveolarni nazal [n]}

Kada stoji ispred alveolara [t], [d] i [n], /N/ se ostvaruje kao alveolarno [n], primjerice u annai [ãnnai] 'vođenje', sandai [sãndai] 'tri (mašine)'. U riječi annai /N/ predstavlja prvi segment geminiranoga alveolarnog nazala /n/.

\section{velarni nazal $[\mathrm{y}]$}

U riječima ispred velara [k] i [g], japanski morni nazal realizira se kao [n], kao u tenki [tẽnki] 'vrijeme (kao atmosferska pojava)', ongaku [õygaku] 'muzika'.

\section{alveopalatalni nazal [n]}

/N/ se ispred [n] ostvaruje kao alveopalatalni nazal [n], kao u nannichi [nãnniţ̧i] 'koji dan'. Taj se glas promatra u grupi alveolarnih nazala, s tim što ga odlikuje i palatalnost.

U ispitivanju provedenom za potrebe ovoga rada korišteno je 16 riječi u kojima je promatran po jedan od gore navedenih 8 ostvaraja: [N], [ũ] (ispred vokala), [ũu] (ispred poluvokala), [ũ] (ispred frikativa i njihovih alofona), [m], [n], [n] ili [n].

9 Kanji ili kineski karakter koji se koristi u japanskoj grafiji pored dva fonetska pisma. 


\section{IZGOVORNA ODSTUPANJA U KONTEKSTU KOMUNIKACIJSKE KOMPETENCIJE}

Izgovorna kompetencija predstavlja bitan dio komunikacijske kompetencije, a da bi se ona stekla, potrebno je otklanjati izgovorna odstupanja. Prvi je korak prema tome cilju njihov opis i analiza. U dokumentu pod nazivom „Standard poučavanja japanskoga kao stranog jezika“10 izgovorna se kompetencija spominje kao sastavnica jezične kompetencije, skupa s kompetencijama u vezi s vokabularom, gramatikom, pismom i pravopisom. Jezična pak kompetencija predstavlja dio komunikacijske kompetencije, čije su preostale dvije sastavnice sociolingvistička i pragmatička kompetencija (Kokusai kōryū kikin 2010: 8). Osim kratkoga objašnjenja da se pod izgovornom kompetencijom podrazumijeva vladanje fonemima japanskoga jezika, navedeni se dokument ne bavi konkretnim aspektima izgovora, no upute od praktičnoga značaja mogu se naći u priručniku iz nastave japanskoga jezika u izdanju iste organizacije (Kokusai kōryū kikin 2018). Kao alofoni /N/ navode se spomenuti glasovi [N], [m], [n], [n], [n] te nazalni vokal neodređenoga mjesta artikulacije [ũ], no posebnost ovoga priručnika leži u tome da se ostvaraj u međuvokalskom položaju ispred visokih vokala [e] i [i], poluvokala [j] i drugih palatalnih konsonanata opisuje na drukčiji način od gore navedenih. Naime, bilježi se kao nazalizirani vokal [î]. Tako se, primjerice sen'en 'tisuća jena' bilježi kao [seĩen] (a ne [seũen]), a hon'yaku 'prijevod' kao [hoĩjaku] (a ne [hoũjaku]]). U priručniku se jasno navodi da je sen'en pogrešno izgovoriti [seneN], s alveolarnim [n] (Kokusai kōryū kikin 2018: 64-65).

Kao što će ispitivanje pokazati, pri izgovoru mornoga nazala /N/ kod učenika dolazi do odstupanja. Ipak, nemaju sva odstupanja jednak značaj. U literaturi o usvajanju stranoga jezika navodi se razlika između fonetskih $\mathrm{i}$ fonoloških odstupanja. Citirajući Jakobsona (1939), Desnica-Žerjavić (1993: 126) navodi da postoje tri vrste najgrubljih interferencija, odnosno pogrešaka proisteklih iz utjecaja materinskoga jezika, koje ometaju komunikaciju: (a) "defonemizacija“ (ukidanje opozicija), (b) „fonemizacija“ (uvođenje novih opozicija) i (c) „transfonemizacija“ (reinterpretacija razlika uslijed shvaćanja da su redundantna obilježja relevantna). Ove pogreške remete komunikaciju upravo zato što se tiču razlikovnih obilježja. U istom radu Desnica-Žerjavić (1993: 126) spominje i četvrtu grupu interferencija, koju Weinreich (1953) naziva (d) supstitucijom fonema koji su „identično definirani u oba jezika,

10 Dokument je sastavljen po ugledu na CEFR (Council of Europe, 2001). 
ali se razlikuju u fonetskoj realizaciji“. Četvrta se grupa, dakle, odnosi na odstupanja koja ne utječu na razlikovnost, premda, kako navodi, predstavljaju tvrdokorni izvor stranoga akcenta. Takva odstupanja imaju značaj samo na fonetskoj razini. Od navedene 3 vrste fonološkoga odstupanja za ovaj će rad biti značajna defonemizacija. ${ }^{11}$

S druge točke gledišta, odstupanja se također mogu podijeliti na (a) pogreške kompetencije, odnosno sustavne ili prave pogreške (DesnicaŽerjavić 1998: 73), koje se javljaju zbog toga što pojedini elementi ciljnoga jezika nisu usvojeni na adekvatan način, i na (b) pogreške performancije, odnosno slučajne lapsuse, do kojih dolazi zbog umora ili u žurbi.

\section{ZADATAK ISTRAŽIVANJA I HIPOTEZA}

U odjeljku 3 pokazano je da se /N/ u različitim kontekstima realizira kao [N], [ũ], [m], [n], [y] ili [n]. Usporedimo li ovu skupinu nazala s glasovima u hrvatskome, primijetit ćemo da kao fonemi postoje [m], [n], [n], dok [n] postoji u hrvatskome kao alofon ispred [k] i [g] kao u primjerima stanka, banka. S druge strane, u hrvatskome ne postoje uvularni nazal [N] i skupina vokala neodređenoga mjesta artikulacije koju bilježimo kao [ũ], posebno inačica koja se javlja u međuvokalskom položaju. No kada je riječ o [ũ] ispred frikativa [s] i [z] te njihovih alofona kao što su [c] i [ [̧]z], može se reći da se njihov akustički dojam ne razlikuje znatno od alofona fonema $/ \mathrm{n} / \mathrm{u}$ hrvatskome ${ }^{12}$, i to onih koji se javljaju u riječima menza, branša, alijansa ${ }^{13}$. Zatim, u položaju ispred poluvokala [u] i [j] akustički je dojam toga glasa blizak fonovima koje nalazimo u hrvatskome u riječima injekcija i invalid u brzom govoru, odnosno u inačici izgovora pri kojoj je odsutan dodir vrha jezika s dentalnim ili alveolarnim dijelom.

Iz gore navedenog može se izvesti pretpostavka da će se teškoće pri izgovoru za hrvatske učenike japanskoga jezika javljati u slučajevima gdje se javljaju uvularni nazal [N] i vokal neodređenoga mjesta artikulacije [ũ], dok se kod [m], [n], [n], [n] teškoće u izgovoru ne predviđaju.

11 Što se tiče klasifikacije izgovornih odstupanja te podjele na fonološku i fonetsku kompetenciju u kontekstu hrvatskoga jezika, pogledati Šporčić (2020).

12 Što se tiče primjera za dvočlane skupine hrvatskih fonema, pogledati Turk (1992: 74).

13 Što se tiče opisa alofona hrvatskoga alveolarnog nazala /n/, pogledati Brozović (2007: 184-185). 


\subsection{EMPIRIJSKO ISTRAŽIVANJE}

Provedeno empirijsko istraživanje imalo je za cilj utvrditi u kojoj su mjeri studenti usvojili izgovor mornoga nazala u različitim glasovnim kontekstima, odnosno koji im ostvaraji zadaju najviše poteškoća i koje vrste odstupanja postoje. Također, provjerava se točnost hipoteze da će najviše odstupanja biti kod uvularnoga nazala [N] i vokala neodređenoga mjesta artikulacije [ũ]. Osim toga, važan je zadatak ovoga istraživanja utvrditi koja odstupanja imaju fonološki, a koja fonetski značaj.

\subsection{METODOLOGIJA}

\section{INFORMANTI}

Svi su ispitanici studenti Japanskoga jezika i kulture na Filozofskom fakultetu, Sveučilište Jurja Dobrile u Puli. U ispitivanju je sudjelovalo ukupno 24 studenata, od kojih 15 početne razine i 9 srednje razine japanskoga jezika. Studenti početne razine do ispitivanja su završili prvi semestar prve godine i upoznali se sa svim relevantnim fonetskim i fonološkim pravilima vezanima uz izgovor, uključujući i morni nazal /N/. U okviru nastave za prvu godinu učenja koristi se udžbenik Minna no nihongo ${ }^{14}$, a na trećoj se godini koristi udžbenik Tobira ${ }^{15}$. Uz oba udžbenika studenti dobivaju i slušne zapise, a izgovor se utvrđuje na govornim vježbama.

U sklopu ispitivanja za potrebe ovoga rada svaki je ispitanik dobio zadatak pročitati 16 riječi koje sadrže morni nazal, napisane fonetskim pismom hiragana (za razliku od logografskoga pisma, tj. kineskih karaktera, kojim bi se iste riječi inače zapisivale s jedne strane ili pak drugoga fonetskog pisma, katakana, s druge).

\section{RIJEČI U FOKUSU}

U Tablici 1 navedene su riječi korištene u ispitivanju. Prvi red sadrži opis 8 različitih konteksta u kojima se /N/ javlja, odnosno ispred kojeg segmenta stoji u danoj riječi, drugi red pokazuje fon kojim se /N/ u tim riječima ostvaruje, a treći red sadrži primjere za ovih 8 konteksta. Pri izboru se vodilo računa da to budu riječi koje su studentima poznate: Nihon [nihõN]

14 Surīei nettowāku (2019).

15 Oka et al. (2020). 
'Japan', yon [yõN] 'četiri', san'en [sãũen ] 'tri jena', kan'i [kãũi] 'priručno', sanpo [sãmpo] 'šetnja', sanmai [sãmmai] 'tri (tanka predmeta)', annai [ãnnai] 'vođenje', sandai [sãndai] 'tri (mašine)', tenki [tẽnki] 'vrijeme (kao atmosferska pojava)', ongaku [õngaku] 'muzika', sensei [sẽũ see] 'učitelj',

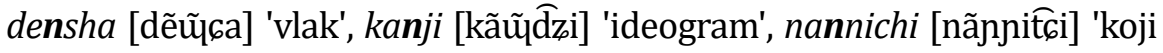
dan', denwa [dẽũua] 'telefon', kin'yoobi [kĩũjoobi] 'petak'. ${ }^{16}$

Tablica 1. Popis riječi za ispitanike

\begin{tabular}{|c|c|c|c|c|c|c|c|c|c|}
\hline & $\begin{array}{c}\text { Redni } \\
\text { broj } \\
\text { skupine }\end{array}$ & 1 & 2 & 3 & 4 & 5 & 6 & 7 & 8 \\
\hline 1 & $\begin{array}{l}\text { /N/ stoji } \\
\text { ispred }\end{array}$ & stanke & $\begin{array}{c}{[\mathrm{a}],[\mathrm{i}],} \\
{[\mathrm{u}],[\mathrm{e}],} \\
{[\mathrm{o}]}\end{array}$ & {$[u],[j]$} & $\begin{array}{c}\text { [ф], [s], } \\
{[\mathrm{z}],[\mathrm{c}],} \\
{[\mathrm{c}],[\mathrm{d} \mathrm{d}]} \\
{[\mathrm{h}]} \\
\end{array}$ & $\begin{array}{c}{[\mathrm{p}],[\mathrm{b}],} \\
{[\mathrm{m}]}\end{array}$ & $\begin{array}{l}{[\mathrm{t}],[\mathrm{d}],} \\
{[\mathrm{n}],[\mathrm{ts}]}\end{array}$ & [n] & {$[\mathrm{k}],[\mathrm{g}]$} \\
\hline 2 & $\begin{array}{c}\text { fon } \\
\text { kojim se } \\
\text { ostvaruje }\end{array}$ & [N] & [ũ] & [ũ ] & [ũ ] & {$[\mathrm{m}]$} & [n] & [n] & [y] \\
\hline 3 & primjeri & $\begin{array}{c}\text { nihon, } \\
\text { yon }\end{array}$ & $\begin{array}{l}\text { san'en, } \\
\text { kan'i }\end{array}$ & $\begin{array}{c}\text { denwa } \\
\text { kin'yoobi }\end{array}$ & $\begin{array}{c}\text { sensei, } \\
\text { densha, } \\
\text { kanji }\end{array}$ & $\begin{array}{l}\text { sanpo, } \\
\text { sanmai }\end{array}$ & $\begin{array}{l}\text { annai, } \\
\text { sandai }\end{array}$ & nannichi & $\begin{array}{l}\text { tenki, } \\
\text { ongaku }\end{array}$ \\
\hline
\end{tabular}

Budući da se u uvjetima pandemije nastava nije provodila u učionici, pri ispitivanju je korištena aplikacija Zoom za videokonferenciju. Jedna od funkcija koju ova aplikacija omogućava je i snimanje. Studenti su pozivani u virtualnu sobu gdje su im potom prezentirane riječi putem grupnoga razgovora. Ispitanicima su bili uključeni kamera i mikrofon te su dobili uputu da budu licem okrenuti prema kameri da bi se jasno moglo vidjeti kako artikuliraju glasove. Ocjenjivači su dobili snimku cjelokupnoga ispitivanja, a ne samo izdvojenih riječi. Ocjenjivačima je rečeno da se fokusiraju na izgovor mornoga nazala, a ne na druge elemente gdje bi moglo doći do odstupanja, kao što je naglasak ili izgovor drugih segmenata dane riječi.

\section{OCJENJIVAČI}

U ocjenjivanju točnosti izgovora na osnovi slušne percepcije sudjelovala su tri izvorna govornika japanskoga jezika, od kojih se dva bave nastavom japanskoga jezika, a jedan prevođenjem s hrvatskoga. Ocjenjivači su imali zadatak ocijeniti je li morni nazal u danoj riječi izgovoren u skladu s pravilima izgovora japanskoga jezika ili ne, specificirajući po čemu izgovor koji je

16 Od navedenih riječi samo je kan'i' 'priručno' riječ s više razine, no pretpostavka je bila da to nema utjecaja na točnost izgovora jer su sve riječi bile zapisane fonetskim pismom koje su studenti savladali u najranijoj fazi učenja japanskoga jezika. 
ocijenjen neodgovarajućim odstupa. Za tu svrhu sastavljen je popis značajki po kojima bi, po slušnom dojmu, dane realizacije mogle odstupati, kao što su mjesto tvorbe, trajanje mornoga nazala, javlja li se nepotrebna stanka između mornoga nazala i sljedeće more, je li /N/ nedovoljno nazalan. Osim toga, ako je izgovor ocijenjen pogrešnim, bilo je također potrebno pojasniti je li (a) izgovor /N/ u datoj riječi takav da se njegova razlikovnost gubi te se željeno značenje riječi ne raspoznaje ili je (b) izgovor /N/ u datoj riječi takav da ne utječe na njegovu razlikovnost, bez obzira na izvjesno odstupanje. U prvom slučaju smatramo da je riječ o fonološkom, a u drugom o fonetskom odstupanju.

Za potrebe ovoga ispitivanja kriteriji su odstupanja definirani na sljedeći način.

(1) $\mathrm{Za} / \mathrm{N} /$ ispred stanke odstupanjem se smatra ako, prema percepciji ocjenjivača, a) nema dovoljno izraženo obilježje nazalnosti, ako b) nema odgovarajuću dužinu tj. ne traje jednu moru te ako ima c) neodgovarajuće mjesto tvorbe. U ovome radu, za koji je bitan kontekst nastave japanskoga kao stranoga jezika, polazimo od stajališta da se /N/ ispred stanke ${ }^{17}$ realizira kao uvularni nazal ${ }^{18}$, kao što se navodi i u priručniku za poučavanje izgovora (Kokusai kōryū kikin 2018: 62).

(2) Kod vokala neodređenoga mjesta artikulacije [ũ] u međuvokalskom položaju odstupanje se utvrđuje ako izgovoreni glas nema dovoljno izraženo obilježje nazalnosti, ili ako se artikulira kao konsonant, s nekom vrstom zapreke (npr. alveolarno) ili ne traje jednu moru.

(3) Kod vokala neodređenoga mjesta artikulacije [ũ] ispred poluvokala i frikativa, uključujući i njihove alofone, odstupanje se utvrđuje ako izgovoreni glas nema dovoljno izraženo obilježje nazalnosti ili ne traje jednu moru ili ima nepotrebnu stanku.

17 Premda se dugo smatralo da je /N/ ispred stanke uvularni nazal, stvarna je situacija u suvremenome standardnom japanskom jeziku veoma komplicirana. /N/ se ispred stanke realizira s nemalim brojem individualnih varijacija. Poznato je da se kod određenoga broja govornika /N/ na kraju riječi realizira kao [m] (Nogita i Yamane 2015), a kod nekih kao nazalni vokal neodređenoga mjesta artikulacije, te se primjerice en „krug“, može realizirati kao [eN] i kao [eũ ], odnosno i kao uvularni nazal i kao nazalni vokal (Okada 1991:95, citirao Akamatsu 1997: 58, 299). Prema najnovijim istraživanjima koja se bave upravo glasom /N/ ispred stanke (Maekawa 2021), koristeći magnetnu rezonancu u stvarnom vremenu, utvrđeno je da se kod dijela izvornih govornika /N/ ispred stanke realizira alveolarno, ovisno o glasu koji mu prethodi.

18 Za ovakvo stajalište nije bila nevažna okolnost da se u slušnim materijalima udžbenikâ koji se koriste u nastavi na Sveučilištu Jurja Dobrile u Puli /N/ ispred stanke javlja kao uvularni nazal. Još jedan bitan razlog za ovakvo stajalište leži u tome da je u nastavi primijećeno da učenici koji artikuliraju uvularni nazal ispred stanke također u velikom broju slučajeva uspijevaju ispravno artikulirati i nazalni vokal neodređenoga mjesta tvorbe [ũ ] u međuvokalnom položaju. 
(4) Kod [m], [n], [n] i [n] odstupanje se utvrđuje ako izgovoreni glas nema dovoljno izraženo obilježje nazalnosti ili je pogrešnim ocijenjeno mjesto tvorbe, (odnosno nije, redom, bilabijalno, alveolarno, velarno i alveolopalatalno) ili se artikulira prekratko, ili uz nepotrebnu stanku.

Navedeni kriteriji mogu se razložiti na sljedeće sastavnice:

(P) prekratko, /N/ ne traje jednu moru,

(M) mjesto tvorbe odstupa,

(S) javlja se suvišna stanka između /N/ i sljedeće more,

(N) nedovoljna nazalnost.

Treba naglasiti kako slušni dojam da je /N/ izgovoreno prekratko zapravo predstavlja posljedicu alveolarnoga mjesta tvorbe. Može se reći da su kriteriji (P) i (M) blisko povezani.

Na pitanje je li dano odstupanje fonološkoga ili fonetskoga značaja ne može se dati odgovor samo na temelju ovdje navedena 4 kriterija u izolaciji. Da bi se to utvrdilo, potrebno je usmjeriti pozornost na kontekst, tj. riječ u cjelini. 


\section{PODATCI I ANALIZA}

Podatci su analizirani zasebno za prvu i zasebno za treću godinu, za svaku od 16 riječi posebno, a zatim je 16 riječi podijeljeno u 8 skupina koje odražavaju 8 različitih ostvaraja u 8 konteksta. Radi preglednosti, Tablica 2 prikazuje sadržaj kolona A-K koje se navode u Tablici 3.

\section{Tablica 2.}

\begin{tabular}{|c|c|}
\hline A & riječ koju su ispitanici imali zadatak naglas pročitati \\
\hline B & broj odstupanja koje je za danu riječ zabilježio Ocjenjivač 1 \\
\hline $\mathrm{C}$ & tipovi odstupanja koje je za danu riječ zabilježio Ocjenjivač 1 \\
\hline $\mathrm{D}$ & broj odstupanja koje je za danu riječ zabilježio Ocjenjivač 2 \\
\hline E & tipovi odstupanja koje je za danu riječ zabilježio Ocjenjivač 2 \\
\hline $\mathrm{F}$ & broj odstupanja koje je za danu riječ zabilježio Ocjenjivač 3 \\
\hline G & tipovi odstupanja koje je za danu riječ zabilježio Ocjenjivač 3 \\
\hline $\mathrm{H}$ & ukupan broj odstupanja za danu riječ koji se dobije kao zbroj kolona B+D+F \\
\hline I & $\begin{array}{l}\text { postotak odstupanja za danu riječ kao odnos zbroja odstupanja u koloni H i ukupno broja } \\
\text { ocijenjenih izgovora ( } 45=15^{*} 3 \text { za prvu, a } 27=9 * 2 \text { za treću godinu). Primjerice, za riječ nihon } \\
\text { na prvoj je godini zabilježeno sveukupno } 5 \text { odstupanja, što u odnosu na } 45 \text { ocijenjenih } \\
\text { izgovora daje } 11,11 \%\end{array}$ \\
\hline $\mathrm{J}$ & prosjek odstupanja za danu kategoriju. 16 riječi raspoređeno je u 8 kategorija kao u Tablici 1 \\
\hline $\mathrm{K}$ & $\begin{array}{l}\text { ako je odstupanje na fonološkoj razini, upisuje se zvjezdica }\left({ }^{*}\right) \text {, a ako je odstupanje na } \\
\text { fonetskoj razini, ne upisuje se ništa }\end{array}$ \\
\hline
\end{tabular}

Tip odstupanja naveden je za svakoga ocjenjivača posebno u kolonama C, E i G. Primjerice, kod riječi nihon vidimo da u koloni C stoji 5MP, što znači da je Ocjenjivač 1 zabilježio da je svih 5 odstupanja u vezi s mjestom artikulacije (M) i da je artikulirano prekratko (P).

Zatim, u koloni J „Skupni postotak“ prikazan je postotak odstupanja po skupinama. Podijeljeno je 16 riječi u 8 skupina koje ilustriraju 8 različitih ostvaraja mornoga nazala. U kolonu K unesena je zvjezdica kod odstupanja na fonološkoj razini, dok je polje ostavljeno prazno kod onih na fonetskoj. Zatim, na dnu svake tablice naveden je ukupan apsolutni broj odstupanja i prosjek odstupanja za danu razinu za sve riječi zajedno. 
Tablica 3. Rezultati za prvu godinu: odstupanja pri izgovoru mornoga nazala /N/ u različitim kontekstima

\begin{tabular}{|c|c|c|c|c|c|c|c|c|c|c|c|}
\hline & A & B & $\mathrm{C}$ & $\mathrm{D}$ & $\mathrm{E}$ & $\mathrm{F}$ & G & $\mathrm{H}$ & I & $\mathrm{J}$ & $\mathrm{K}$ \\
\hline & & \multicolumn{2}{|c|}{ Ocjenjivač 1} & \multicolumn{2}{|c|}{ Ocjenjivač 2} & \multicolumn{2}{|c|}{ Ocjenjivač 3} & & & & \\
\hline & Riječ & \begin{tabular}{|c|} 
Broj \\
o.
\end{tabular} & $\begin{array}{c}\text { Tip } \\
\text { o. }\end{array}$ & $\begin{array}{c}\text { Broj } \\
\text { o. }\end{array}$ & Tip o. & $\begin{array}{c}\text { Broj } \\
\text { o. }\end{array}$ & Tip o. & Ukupno & Postotak\% & $\begin{array}{c}\text { Skupni } \\
\text { postotak }\end{array}$ & \\
\hline 1 & nihon & 5 & $5 \mathrm{MP}$ & 0 & & 0 & & 5 & 11,11 & \multirow{2}{*}{11,11} & \\
\hline 2 & yon & 5 & $5 \mathrm{MP}$ & 0 & & 0 & & 5 & 11,11 & & \\
\hline 3 & san'en & 15 & $15 \mathrm{M}$ & 15 & $15 \mathrm{M}$ & 10 & $10 \mathrm{M}$ & 40 & 88,89 & \multirow{2}{*}{92,22} & $*$ \\
\hline 4 & kan'i & 14 & $14 \mathrm{M}$ & 15 & $15 \mathrm{M}$ & 14 & $14 \mathrm{M}$ & 43 & 95,56 & & $*$ \\
\hline 5 & kin'yoobi & 1 & $1 \mathrm{P}$ & 4 & $\begin{array}{l}2 \mathrm{M} ; \\
2 \mathrm{MP}\end{array}$ & 0 & & 5 & 11,11 & \multirow{2}{*}{5,56} & \\
\hline 6 & denwa & 0 & & 0 & & 0 & & 0 & 0,00 & & \\
\hline 7 & sensei & 1 & $1 \mathrm{P}$ & 0 & & 0 & & 1 & 2,22 & \multirow{3}{*}{3,70} & \\
\hline 8 & densha & 2 & $2 \mathrm{P}$ & 0 & & 0 & & 2 & 4,44 & & \\
\hline 9 & kanji & 1 & $1 \mathrm{P}$ & 1 & $1 \mathrm{P}$ & 0 & & 2 & 4,44 & & \\
\hline 10 & sanpo & 3 & $3 \mathrm{M}$ & 0 & & 0 & & 3 & 6,67 & \multirow[b]{2}{*}{10,00} & \\
\hline 11 & sanmai & 3 & $\begin{array}{l}2 \mathrm{M} \\
1 \mathrm{~S}\end{array}$ & 3 & $3 \mathrm{M}$ & 0 & & 6 & 13,33 & & \\
\hline 12 & annai & 1 & $1 \mathrm{~S}$ & 1 & $1 \mathrm{~S}$ & 0 & & 2 & 4,44 & \multirow{2}{*}{3,33} & \\
\hline 13 & sandai & 0 & & 1 & $1 \mathrm{P}$ & 0 & & 1 & 2,22 & & \\
\hline 14 & nannichi & 1 & $1 \mathrm{P}$ & 3 & $\begin{array}{l}1 \mathrm{P} \\
2 \mathrm{~S}\end{array}$ & 0 & & 4 & 8,89 & 8,89 & \\
\hline 15 & tenki & 0 & & 0 & & 0 & & 0 & 0,00 & \multirow{2}{*}{2,22} & \\
\hline 16 & ongaku & 1 & $1 \mathrm{P}$ & 1 & $1 \mathrm{P}$ & 0 & & 2 & 4,44 & & \\
\hline \multicolumn{8}{|c|}{ Ukupno odstupanja: } & 121 & & & \\
\hline \multicolumn{9}{|c|}{ Ukupni prosjek odstupanja: } & 16,81 & & \\
\hline
\end{tabular}

Tip odstupanja: P - prekratko; $\mathrm{M}$ - mjesto tvorbe; $\mathrm{S}$ - suvišna stanka; N nedovoljna nazalizacija 
Tablica 4. Rezultati za treću godinu: odstupanja pri izgovoru mornoga nazala /N/ u različitim kontekstima

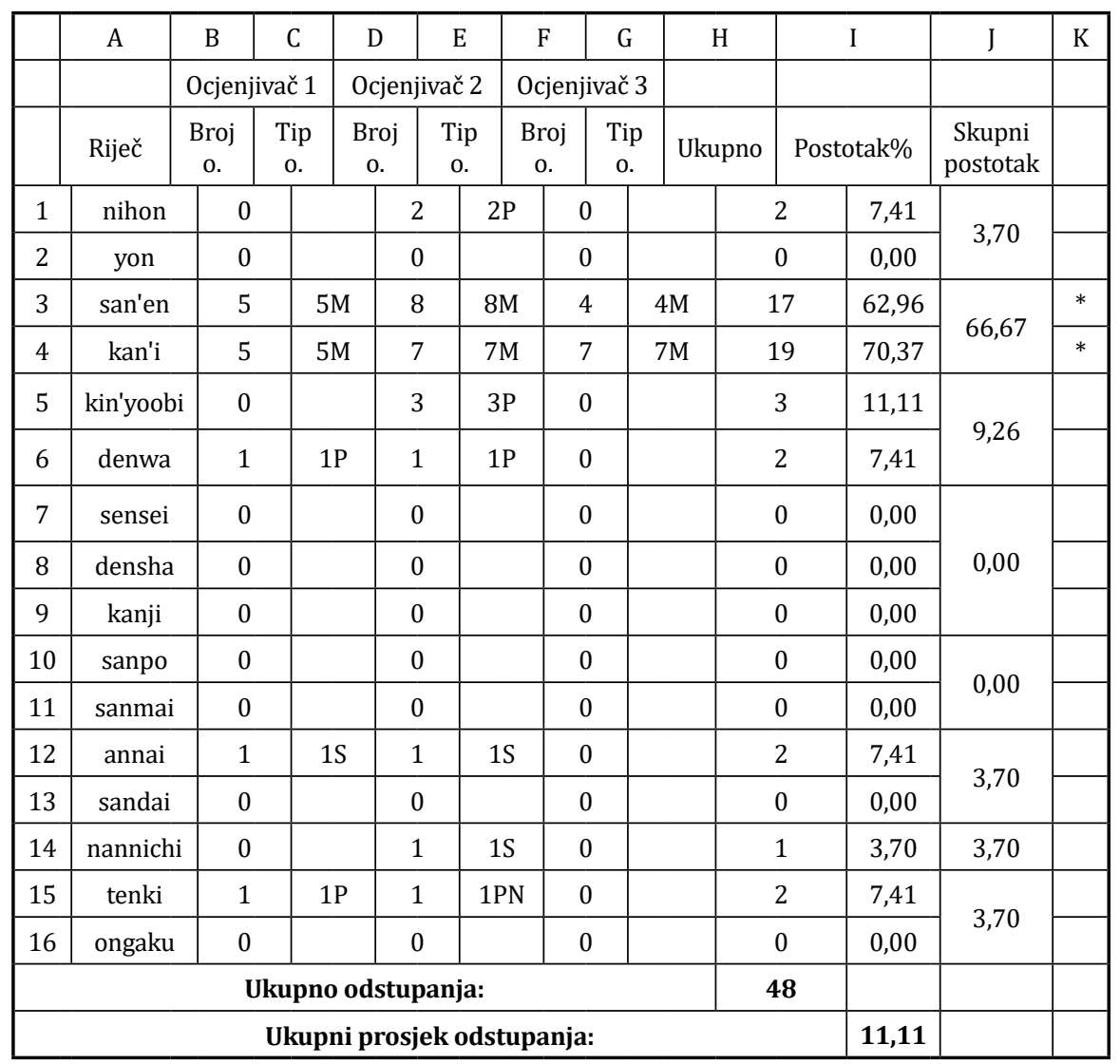

Tip odstupanja: P - prekratko; M - mjesto tvorbe; S - suvišna stanka; N nedovoljna nazalizacija

U izgovoru /N/ ispred stanke te ispred vokala i poluvokala odstupanje po mjestu tvorbe sastoji se u tome što se zamjenjuje alveolarnim [n].

Iz tablica se jasno može vidjeti da se fonološka odstupanja, obilježena zvjezdicom u koloni K, javljaju kod riječi san'en i kan'i. Na obje je razine učenički izgovor najviše odstupao upravo ovdje, kod izgovora /N/ ispred vokala, odnosno u međuvokalskom položaju. Na prvoj godini učenja $92 \%$ učenika nije pravilno izgovorilo ovaj glas, dok je na trećoj godini s blizu $67 \%$ neadekvatnih realizacija ovo odstupanje i dalje veoma prisutno. Korištenje alveolarnog [n] umjesto vokala neodređenoga mjesta artikulacije [ũ] u međuvokalskom kontekstu predstavlja fonološku pogrešku pri kojoj pogrešan fonem izaziva narušavanje komunikacije. U literaturi se često navode 
minimalni parovi tani 'dolina' i tan'í'ETCS bod', kani 'kraba'i kan'ï 'priručno', nana 'sedam' i nan'a 'Južna Afrika', u kojima je ključno artikulirati vokal [ũ], a ne konsonant [n]. Po klasifikaciji Desnice-Žerjavić (1998: 79) to bi bila distinktivna pogreška, odnosno pogreška koja se tiče distinktivnoga obilježja. Konkretnije, iz aspekta vrste fonološkoga odstupanja, to je defonemizacija, odnosno ukidanje opreke alveolarnoga / $\mathrm{n}$ / i mornoga nazala / $\mathrm{N} / \mathrm{u}$ ciljnom jeziku. Osim toga, bitno je uočiti da ovo odstupanje remeti ritam japanskoga jezika. Naime, kada se ispred vokala izgovori alveolarno, /N/ u potpunosti gubi funkciju more, svodeći se tek na prvi segment narednoga sloga, te se prozodijska riječ hon o 'knjigu' umjesto s tri more /ho.n.o/ pogrešno izgovara s dvije /ho.no/ (Kondo 2012: 28).

Na temelju broja pogrešaka na obje razine, te perzistentnosti odstupanja na trećoj godini učenja, zaključuje se da je ovo sustavna pogreška, odnosno pogreška kompetencije, a ne lapsus.

U odjeljku 2 iznesena je pretpostavka da će ocjenjivači uočiti odstupanje kod /N/ispred stanke jer se tu realizira kao uvularni nazal [N] koji ne postoji u hrvatskome, a i rijedak je u svjetskim jezicima. Akamatsu (1997: 135) navodi da taj glas postoji u eskimskom i nekim jezicima domorodačkih naroda Sjeverne Amerike. No slušni je dojam realizacija ovoga glasa takav da ocjenjivači nisu registrirali odstupanje u visokom postotku. Primjećuje se da je postotak odstupanja na prvoj godini oko $11 \%$, a kod treće godine skoro trostruko niži, ali da ipak i dalje postoji. Kvalitativno gledano, odstupanja se većinom sastoje u tome da je /N/ ostvareno alveolarno i/ili prekratko ${ }^{19}$. Ipak, ispred stanke ne postoji razlikovnost između alveolarnoga [n] i uvularnoga [N] te se ne može reći da zamjena uvulara nazalom može narušiti komunikaciju.

Ispred poluvokala [j] dolazi do odstupanja u istom postotku na obje razine, i to tako što su ispitanici artikulirali konsonant [n] ispred poluvokala umjesto vokala [ũ], ili se artikulacija danoga glasa doimala prekratko. Ispred poluvokala [u] dvije instance ocijenjene su prekratkima te je stoga prema izračunu postotak odstupanja za treću godinu kod riječi denwa bio 7,41 \%.

19 U skorašnjem istraživanju o artikulaciji /N/ kod govornika japanskoga čiji je materinski jezik engleski Mizoguchi et al. (2019) pomoću ultrazvuka utvrđuju da se na sve tri razine, od početne do napredne, pri izgovoru uvularnoga nazala [N] koji se javlja ispred stanke primjećuje alveolarni artikulatorni pokret sličan onome pri artikulaciji /n/ u engleskome. 
Za ovo se odstupanje također ne može reći da je fonološko, već se smatra da ima fonetski karakter ${ }^{20}$.

Usporedbom broja i vrste nazala u fonološkom sustavu dvaju jezika utvrđeno je da glasovi [m, n, n, n] postoje u oba jezika te da se zbog toga ne očekuje da studenti odstupaju u izgovoru /N/ koje se realizira ovim fonovima. Međutim, do odstupanja je ipak došlo, i to posebno u riječima gdje se javljaju udvojeni konsonanti, primjerice sanmai, annai, nannichi, gdje je između mora ponekad ubacivana stanka koja tu ne pripada. Dalje, pogreške su se sastojale u tome da su neki učenici izgovarali alveolarno [n] umjesto [m] u [sãmpo] i [sãmmai]. Zatim, [n] u [sãndai] artikulirano je kraće nego što treba.

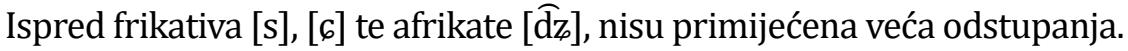

Kod [n], koje se javlja ispred velara, također nisu očekivane pogreške jer isti alofon također ispred /k/ i /g/ postoji i u hrvatskome, ali je uočena pogreška da je [n] artikulirano prekratko te nedovoljno nazalno. Također, u jednoj je realizaciji primijećeno da je tenki izgovoreno alveolarnim [n]. Pretpostavlja se da su odstupanja kao što je tenki ili sanmai s alveolarnim nazalom nastala uslijed treme. Na trećoj godini učenja pogreške su se javljale s najvišom učestalošću kod 2 ispitanika. Ovu vrstu pogrešaka možda bi trebalo smatrati pogreškama performancije (Požgaj Hadži 2002: 17), odnosno lapsusima, a ne pogreškama zbog pogrešno naučenoga izgovora, no tu pretpostavku valjalo bi provjeriti.

Može se zaključiti da sve pogreške, izuzev /N/ u međuvokalskom položaju, imaju fonetski karakter.

Uspoređujući ukupni postotak odstupanja na obje razine, primjećujemo da je na prvoj godini bilo skoro $17 \%$, a na trećoj oko $11 \%$ odstupanja. Prosječni je broj odstupanja po ispitaniku prve godine 8 , dok je ista veličina za studente treće godine 5,3 .

Graf niže prikazuje postotak učestalosti odstupanja u izgovoru fonema /N/ u 8 različitih konteksta. Lijevi se stupac svakoga navedenog konteksta odnosi na prvu, a desni na treću godinu. Na njemu se jasno vidi da je brojčano

20 U slučaju izgovora [n] ispred [j] kao [n], moglo bi doći do narušavanja komunikacije kao što se može vidjeti iz opozicije kinyuu 'popuniti' i kin'yuu 'financije', no takvih odstupanja u ispitivanju nije bilo. 
najznačajnije odstupanje ono koje se odnosi na /N/ u međuvokalskom položaju.

Graf 1. Usporedba učestalosti odstupanja u 8 konteksta kod obje razine

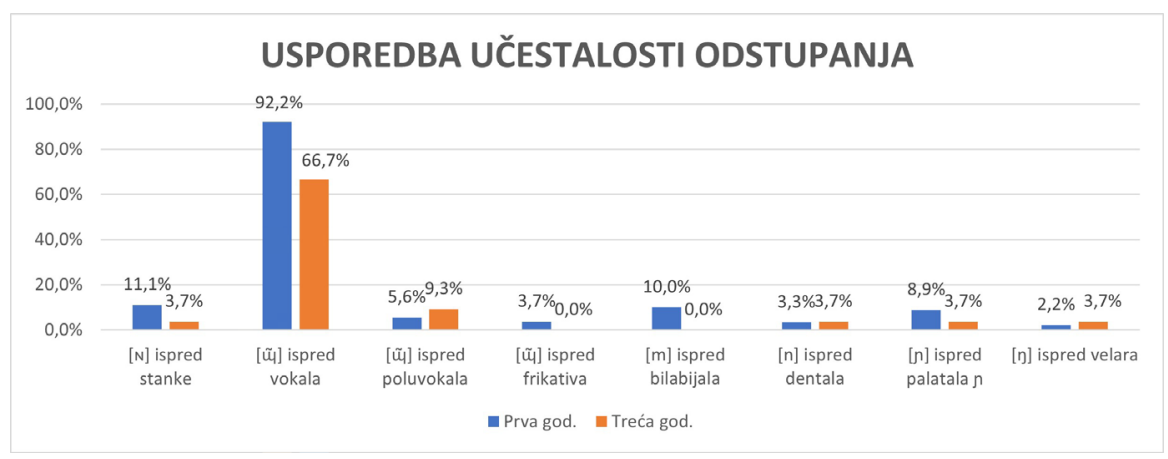

Graf niže prikazuje postotak učestalosti odstupanja u izgovoru [ũ] na obje razine. Prikazane su dvije skupine po 3 stupca. Prvi se stupac u obje skupine odnosi na /N/ u međuvokalskom kontekstu, drugi na /N/ ispred poluvokala, a treći na /N/ ispred frikativa. Prva se tri stupca odnose na početnu razinu, a druga tri na srednju.

Graf 2. Usporedba učestalosti odstupanja u izgovoru

[ũ ] u 3 konteksta kod obje razine

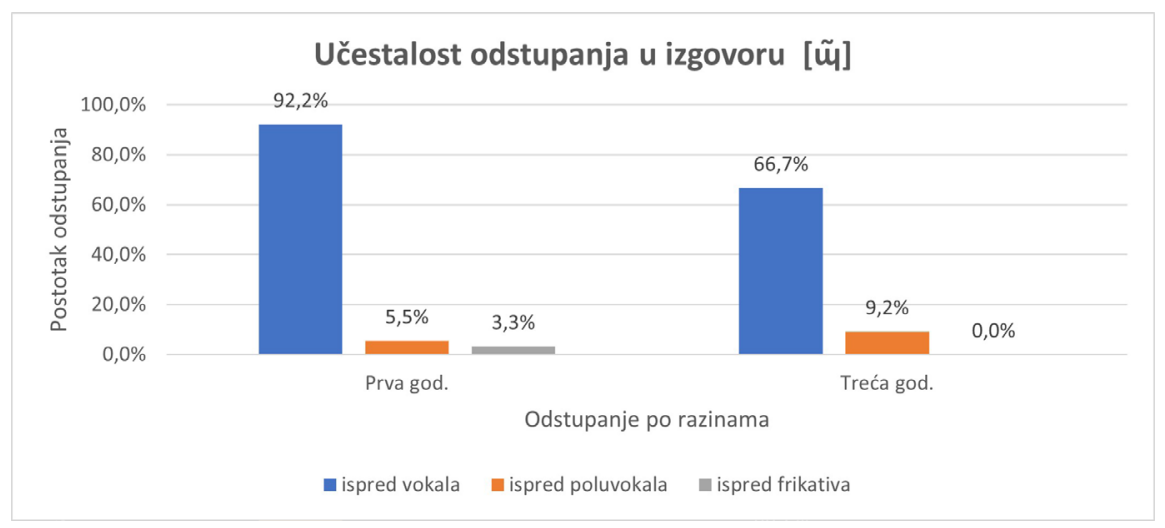

Kao što graf odstupanja pri izgovoru nazalnoga vokala neodređenoga mjesta tvorbe pokazuje, odstupanja su najprisutnija u međuvokalskom položaju, dok su odstupanja ispred poluvokala i frikativa višestruko manja.

Može se postaviti pitanje jesu li ove pogreške karakteristične samo za ovdašnje učenike ili se pak mogu naći i kod drugih učenika japanskoga 
jezika. Na temelju rezultata ankete o interferencijama učenika pri usvajanju japanskoga, na koju su odgovarali nastavnici japanskoga kao stranoga jezika u stranim zemljama, Kondo (2012: 28) je utvrdila da je zamjena /N/ alveolarnim [n] rasprostranjena kod govornika svih 12 jezika ${ }^{21}$ obuhvaćenih anketom. Anketa je obuhvatila brojne aspekte usvajanja japanskoga glasovnog sustava, između ostalog i posebne more /N/, /R/ i /Q/, koje po pravilu izazivaju teškoće pri usvajanju glasovnoga sustava japanskoga jezika. Što se tiče mornoga nazala /N/, Kondo navodi 6 vrsta odstupanja: (1) učenik ga ne čuje, (2) ubacuje ga gdje ne pripada, (3) ne izgovara ga uopće ili nedovoljno dugo, (4) ispred vokala ga zamjenjuje alveolarnim [n], (5) ispred vokala se ubacuje dodatno, nepotrebno [n] ispred /N/i (6) /N/ se zamjenjuje velarnim [n] na pozicijama gdje /N/ nije ispred /k/ i /g/.

Rezultati provedenoga ispitivanja o izgovoru mornoga nazala kod studenata Sveučilišta Jurja Dobrile u Puli pokazuju da se većina odstupanja može podvesti pod grupe (3) i (4) u popisu koji navodi Kondo (2012: 28), odnosno izgovara se ili prekratko ili s alveolarnim mjestom tvorbe. Može se sa sigurnošću reći da ta dva tipa odstupanja ne predstavljaju nikakvu rijetkost u širem kontekstu.

\section{ZAKLJUČAK}

Ovaj se rad bavio određenim aspektima izgovora japanskoga mornog nazala /N/ kod učenika čiji je materinski jezik hrvatski. Provedeno empirijsko istraživanje obuhvatilo je 8 bitnih fonetskih konteksta u kojima se /N/ javlja, radi sagledavanja učestalosti i vrste odstupanja.

Fonološki značaj ima odstupanje kod /N/ u međuvokalskom položaju, koje se javlja kao posljedica interferencije materinskoga jezika. Da bi se izbjegli nesporazumi u komunikaciji, ovaj vid pogreške u izgovoru prioritetno zahtijeva korekciju odgovarajućom metodom. /N/ se tu ostvaruje kao nazalni vokal, koji ima funkciju konsonanta, i traje jednu moru. Iz aspekta podjele odstupanja na pogreške kompetencije i performancije (lapsuse), smatramo da je u pitanju pogreška kompetencije, odnosno sustavna pogreška. S gledišta Jakobsonove (1939) podjele, koju navodi Desnica-Žerjavić (1993: 126), može se reći da tu dolazi do defonemizacije, odnosno ukidanja razlikovnosti između dva različita japanska fonema - alveolarnoga konsonanta /n/ i mornoga

21 Anketom su bili pokriveni: engleski, njemački, francuski, ruski, indonežanski, korejski, tajlandski, kineski, vijetnamski, arapski, turski i mongolski jezik. 
nazala /N/, koji se ovdje ostvaruje kao vokal [ũ]. Osim toga, pri izgovoru alveolara [n] umjesto [ũ], dolazi do gubljenja jedne cijele more kao ritamske jedinice japanskoga jezika, što doprinosi otežanom razumijevanju dane riječi.

Ostala su odstupanja fonetska, kao u riječima tenki i sandai gdje se /N/ izgovara nedovoljno dugo. Ona ne dovode do narušavanja komunikacije, premda identificiraju govornika kao stranca. Za razliku od predviđanja, ispitivanje nije pokazalo veće odstupanje kod uvularnoga nazala, koji se javlja kad /N/ stoji ispred stanke, bez obzira na to što taj glas ne postoji u hrvatskome i rijetko se javlja u svjetskim jezicima. Pretpostavlja se da je takav slušni dojam ocjenjivača bar djelomice u vezi s okolnošću da je ispitivanje provedeno u virtualnom okruženju. Premda odstupanje u izgovoru uvularnoga nazala na kraju nema fonološki značaj, smatramo da ga treba otkloniti. Razlog tomu je shvaćanje da je, kao što navodi Desnica-Žerjavić (1993: 126), usvajanje nerazlikovnih obilježja glasova bitno i za usvajanje razlikovnih obilježja glasova određenoga stranog jezika.

Bi li se odstupanje u izgovoru u istoj mjeri utvrdilo ako bi se ispitivanje provelo direktno, a ne virtualnim putem? Koji je najučinkovitiji način ispravljanja neadekvatnosti izgovora mornoga nazala /N/ u međuvokalskom položaju? Koje se druge pogreške sustavno javljaju kod učenika japanskoga čiji je materinski jezik hrvatski? Odgovore na ova i druga pitanja ostavit ćemo za buduća istraživanja. 


\section{LITERATURA}

AKAMATSU 1997

Tsutomu Akamatsu, Japanese Phonetics, Theory and Practice. Munchen; Newcastle: Lincom Europa, 1997.

BROZOVIĆ 2007

Dalibor Brozović, „Fonologija hrvatskoga standardnog jezika“, u: Glasovi $i$ oblici hrvatskoga književnog jezika, Zagreb 2007.

COUNCIL OF EUROPE 2001

Council of Europe, The Common European Framework of Reference for Languages: Learning, teaching, assessment (CEFR), 2001.

https: //jfstandard.jp/pdf/web_whole.pdf

DESNICA-ŽERJAVIĆ 1993

Nataša Desnica-Žerjavić, „Načela fonetske korekcije ili: razlika između „istih“ glasova hrvatskog i francuskog jezika“, Strani jezici 22-2, Zagreb, 1993, 126-131.

DESNICA-ŽERJAVIĆ 1998

Nataša Desnica-Žerjavić, „Klasifikacija fonetskih grešaka“, Govor, god. 15, 2, Zagreb 1998, 71-101.

FILIPOVIĆ 1986

Rudolf Filipović, Teorija jezika u kontaktu, Zagreb 1986.

HAMADA 1949

Atsushi Hamada, „Sokuon to hatsuon“ [Gemination and mora nasal], Jinbun Kenkyû 11-12, 1949, 91-114.

ITO 1987

Junko Ito, Syllable theory in Prosodic Phonology, Amherst, MA: University of Massachusetts dissertation, 1987.

JAKOBSON 1939

Roman Jakobson, Le development phonologique du langage enfantin et les coherences correspondantes dans les langues du monde, 5 Congres intern. des linguistes, Bruges, 1939.

JELASKA 2004

Zrinka Jelaska, Fonološki opisi hrvatskoga jezika; glasovi, slogovi, naglasci, Zagreb 2004.

KINDAICHI 1972

Haruhiko Kindaichi, Nihongo on'in no kenkyû [Research on Japanese phonology], Tokyo Tokyodo Shuppan, 1972. 
KOKUSAI KŌRYŪ KIKIN 2010

Kokusai kōryū kikin [Japanska fondacija], „JF Nihongo kyōiku standa-do, Shinban, Riyosha no tame no gaidobukku“ [Standard poučavanja japanskog kao stranog jezika, novo izdanje, Vodič za korisnike], 2010.

https://jfstandard.jp/pdf/web_whole.pdf

KOKUSAI KŌRYŪ KIKIN 2018

Kokusai kōryū kikin, Onsei o oshieru [Poučavanje glasovnog sustava], Kokusai kōryū kikin [Japanska fondacija], Tokyo - Hituzi shobō, 2018.

KONDO 2012

Mariko Kondo, „Nihongo gakushūsha no onsei shūtoku ni okeru daiichi gengo tokuyū no kanshō to fuhen gengoteki kanshō - nihongo kyōshi e no anke-to chōsa kara", Waseda daigaku daigakuin bungaku kenkyuka kiyo 3-57, 2012, 21-34.

\section{KUBOZONO 2015}

Haruo Kubozono, Handbook of Japanese Phonetics and Phonology, Berlin, De Gruyter Mouton, 2015.

\section{LABRUNE 2012}

Laurence Labrune The Phonology of Japanese, Oxford Scholarship Online, 2012.

https://oxford.universitypressscholarship.com/view/10.1093/acprof: oso/9780199545834.001.0001/acprof-9780199545834

\section{MAEKAWA 2021}

Kikuo Maekawa, „Production of the utterance-final moraic nasal in Japanese: A real-time MRI study", Published online by Cambridge University Press, 2021. https://www.cambridge.org/core/journals/journal-of-the-internationalphonetic-association/article/production-of-the-utterancefinal-moraicnasal-in-japanese-a-realtime-mri-study/560B70DE7334F30F54E18D04 86785E66

\section{MIZOGUCHI ET AL. 2019}

Ai Mizoguchi, Mark K. Tiede, D. H. Whalen, „Production of the Japanese moraic nasal /N/ by speakers of English: an ultrasound study", International Congress of Phonetic Sciences Proceedings, 2019.

NOGITA - YAMANE 2015

Akitsugu Nogita, Noriko Yamane, Japanese moraic dorsalized nasal stop, 2015.

\section{https://www.researchgate.net/publication/309098684_Japanese_ moraic_dorsalized_nasal_stop}


OKA ET AL. 2020

Mayumi Oka, Michio Tsutsui, Junko Kondo, Shoko Emori, Yoshiro Hanai, Satoru Ishikawa, Jōkyū e no tobira [Prolaz do napredne razine], Kurosio Publishers, Tokyo 2020.

OKADA 1991

Hideo Okada, 'Japanese', in Journal of the International Phonetic Association 21-2, International Phonetic Association, The University of Leeds, 1991, 94-96.

OTAKE et al. 1993

Takashi Otake, Giyoo Hatano, Anne Cutler, Jacques Mehler, „Mora or syllable? Speech segmentation in Japanese". Journal of Memory and Language, 32, 1993, 258-278.

https://psycnet.apa.org/record/1993-44791-001

POŽGAJ HADŽI 2002

Vesna Požgaj Hadži, Hrvaščina in slovenščina v stiku [Hrvatski i slovenski u kontaktu], Ljubljana 2002.

SAITŌ 2003

Yoshio Saitō, Gendai nihongo no onsei, bunsetsuon to onseikigô [Fonetika suvremenoga japanskog jezika, phones and phonetic symbols], Kitahara, Yasuo (ed.), Asakura Nihongo Kôza 3, Tokyo: Asakura Shoten, 2003, 11-21.

SAITŌ 2020

Yoshio Saitō, Nihongo onseigaku nyūmon kaiteiban [Uvod u japansku fonetiku izmijenjeno i dopunjeno izdanje], Tokyo: Sanseido, 2020.

SHIBATANI 1990

Masayoshi Shibatani, Languages of Japan, Cambridge University Press, 1990.

SURĪEI NETTOWĀKU 2019

Surīei nettowāku, Minna no nihongo shokyu I, dainihan, kuroachiago goiyaku [Japanski za svakog, početni nivo 1, drugo izdanje, s prijevodom popisa riječi na hrvatski], 2019.

ŠPORČIĆ 2020

Mateja Šporčić, „Klasifikacija izgovornih odstupanja na početnom stupnju učenja hrvatskoga - glotodidaktički pristup", Strani jezici 49, 2020, 177-198.

TOKI 2010

Satoshi Toki, Nihongo kyōiku karano onsei kenkyū, [Istraživanje japanske fonetike uz osvrt na nastavu japanskog kao stranog jezika], Hituzi shobō, Tokyo, 2010. 


\section{TURK 1992}

Marija Turk, Fonologija hrvatskog jezika, Rijeka 1992.

VANCE 2008

Timothy J. Vance, The Sounds of Japanese, Cambridge University Press, 2008.

VANCE 2018

Timothy J. Vance, „Moras and Syllables“, The Cambridge Handbook of Japanese Linguistics, Y. Hasegawa, Cambridge University Press, 2018.

WEINREICH 1953

Uriel Weinreich, Languages in contact, Mouton, The Hague, 1953.

YOUNGBERG 2021

Connor Youngberg, „Representing the moraic nasal in Japanese: evidence from Tōkyō, Ōsaka and Kagoshima", Glossa: a journal of general linguistics 61, 2021.

https://www.glossa-journal.org/article/id/5443/ 


\section{ZAHVALA}

Ovim putem želim od srca zahvaliti anonimnim recenzentima na iznimno korisnim komentarima, kao i profesoru Takehiku Maruyami na pomoći pri nabavi relevantne literature iz Japana. Na kraju, posebno zahvaljujem profesorici Ireni Srdanović na podršci.

\section{概要}

クロアチア語を母語とする日本語学習者による發音/N/の発話について 日本語の特殊拍である撥音/N/の発話は、クロアチア語を母語とする日本 語学習者にとって、類似する音素が母語に存在しないため、困難な場合が ある。本論文の主旨は、プーラ大学の日本語学習者が、合計 8 の環境に出 現する/N/の異音をいかに発話するかを考察し、間違いのタイプを特定す ることである。また、間違いが確認された場合、/N/の弁別機能が保たれてい るかどうかという観点から間違いの考察を行った。プーラ大学の学生、初級 者14人、中級者 9 人を対象に調査を行った結果、学習レベルに関係なく、母 音前の/N/が間違って $[\mathrm{n}]$ とて発話される傾向が高いことがわかった。先行 研究にしたがって、これを「音素の置き換え」と見なす。その他の環境に現れ る/N/の場合は、標準語とはやや異なる発話が確認されたが、N/の弁別機 能は保たれたと言える。

\section{SUMMARY}

\section{Production of the Japanese moraic nasal /N/ by speakers of Croatian}

The Japanese moraic nasal / $\mathrm{N} /$ is a subspecified nasal segment with a special status in the Japanese sound system. It has various realisations depending on the context. For Japanese language students whose first language is Croatian, /N/ can pose a challenge as it involves phonological processes that do not exist in their mother tongue. The aim of this paper is to determine empirically how their production of /N/ deviates from the standard in 8 contexts in which /N/ occurs. For that purpose, a survey was conducted involving 24 students of the Juraj Dobrila University in Pula, 14 at the beginner and 9 at the intermediate level. The data showed the errors of various frequencies in the pronunciation of / $\mathrm{N}$ / before pause, semivowels, fricatives and other sounds. A highly frequent error with a phonological significance was detected in an intervocalic position, at both levels of learning. Errors regarding / $\mathrm{N} /$ in front of semivowels, fricatives and other consonants did not show phonological, but only phonetic significance. 